ENTREPRENEURSHIP AND SUSTAINABILITY ISSUES

ISSN 2345-0282 (online) http://jssidoi.org/jesi/

2020 Volume 8 Number 2 (December)

http://doi.org/10.9770/jesi.2020.8.2(29)
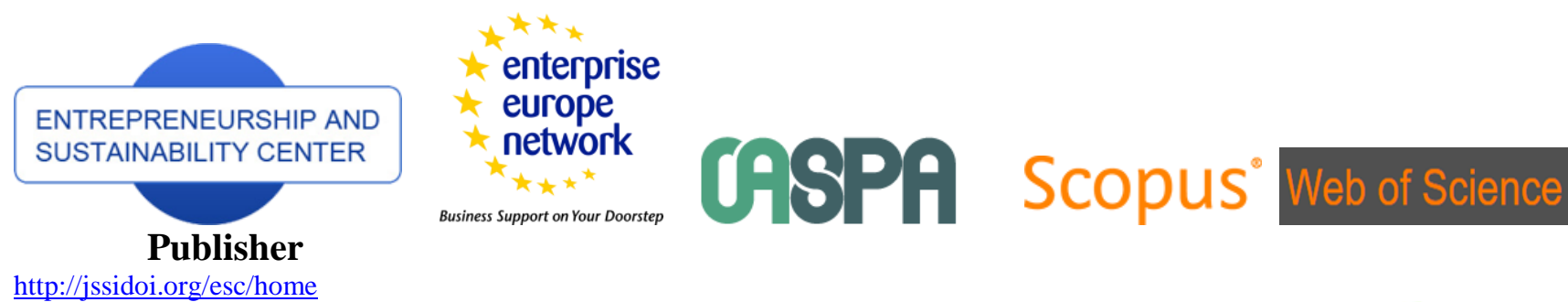

http://jssidoi.org/esc/home

\title{
ARTIFICIAL INTELLIGENCE COMPONENTS AND FUZZY REGULATORS IN ENTREPRENEURSHIP DEVELOPMENT*
}

\author{
Sergii Bogachov ${ }^{1}$, Aleksy Kwilinski ${ }^{2}$, Boris Miethlich ${ }^{3}$, Viera Bartosova ${ }^{4}$, \\ Aleksandr Gurnak ${ }^{5}$ \\ I*PO "Institute for Local and Regional Development", Osipovsky st., 9, apart. 120, Kiev, 04123, Ukraine \\ ${ }^{2}$ The London Academy of Science and Business, 3rd Floor, 120, Baker Street, London, W1U 6TU, England \\ ${ }^{3}$ Comenius University in Bratislava, Odbojárov 10, 82005, Bratislava, Slovak Republic \\ ${ }^{4}$ University of Zilina, Univerzitna 1, 01026, Zilina, Slovak Republic \\ ${ }^{5}$ Financial University under the Government of the Russian Federation, Leningradsky Prospekt 49, Moscow, 125167, Russia \\ E-mail: ${ }^{1 *}$ koaduep@gmail.com (Corresponding author)
}

Received 18 March 2020; accepted 1 September 2020; published 30 December 2020

\begin{abstract}
The article provides a comparative study of the possibility of entrepreneurship development based on fuzzy signals of business activity and applied elements of artificial intelligence. The principal research methods that determine the logic and practical basis of the application of fuzzy logic in entrepreneurship are highlighted. It has been determined that fuzzy modeling is effective when technological processes are too complex for analysis using generally accepted quantitative methods, or when available sources of information in the business environment are interpreted poorly, inaccurately, and indefinitely. It has been shown experimentally that fuzzy logic gives better results compared to those obtained with generally accepted algorithms for analyzing the quality of doing business. A model of a neurofuzzy regulator has been developed and measures for its implementation in the business environment have been proposed. A neural network model in entrepreneurial development has been formed. Studies have shown the possibility of effective use of the principles of artificial intelligence and modeling in solving problems of developing entrepreneurial potential and making business decisions under conditions of uncertainty. This ensures objective and well-grounded decision-making in solving various applied problems of business development and taking into account environmental factors. The applied tasks of supporting the adoption of entrepreneurial decisions in the conditions are formulated; uncertainty; indicating that approaches to decision-making under conditions of uncertainty based on artificial intelligence and fuzzy logic tools are universal and require appropriate careful study and adaptation to a specific applied problem in the business environment.
\end{abstract}

Key words: entrepreneurship; neural network; regulators; linguistic rule; genetic algorithm; object of control

Reference to this paper should be made as follows: Bogachov, S., Kwilinski, A., Miethlich, B., Bartosova, V., Gurnak, A. 2020. Artificial intelligence components and fuzzy regulators in entrepreneurship development. Entrepreneurship and Sustainability Issues, 8(2), 487-499. http://doi.org/10.9770/jesi.2020.8.2(29)

* This research was supported by the project, which has received funding from the Grant No. 1/0544/19 Formation of the methodological platform to measure and assess the effectiveness and financial status of nonprofit organizations in the Slovak Republic 
ENTREPRENEURSHIP AND SUSTAINABILITY ISSUES

ISSN 2345-0282 (online) http://jssidoi.org/jesi/

2020 Volume 8 Number 2 (December)

http://doi.org/10.9770/jesi.2020.8.2(29)

Make your research more visible, join the Twitter account of ENTREPRENEURSHIP AND SUSTAINABILITY ISSUES: @Entrepr69728810

JEL Classification: M21, O16

\section{Introduction}

The problem of considering intellectual activity in entrepreneurship becomes a primary one, unlike the approach of designing traditional artificial intelligence systems from the 'bottom-up' principle based on "rigid models" of information management systems. This approach requires deviation from the concept of "regulatory management models". The basis of a new subject-oriented approach to the entrepreneurship development is research aimed at developing methods based on the selection of psychological features of managerial activity that can be introduced into the model of artificial intelligence (Axelrod, (1997). This position is based on the position of cognitive psychology and attempt to formalize actions typical for the entrepreneur in making commercial decisions and system development. These provisions form the relevance of this study.

\section{Literature Survey}

In modern scientific literature, it is advisable to single out groups of researchers on the development of entrepreneurship based on methods of fuzzy logic and applied elements of artificial intelligence.

1) Constructive and instructive presentation of the development process in entrepreneurship. The traditional developmental command system used is changed to the presentation of educational material in the form of constructor for knowledge building by the "pupil" (Petruzzi, Dada (2002); Snow et. al. (2017). The author's intention is to provide instructions for using the "knowledge constructor" within a particular subject area. As (Walker, (2010); Whitehead and Choate (1994) points out in the model of artificial intelligence development - it is "electronic" technology, wherein the new education system based on artificial intelligence has decision-making power while working with the "designer knowledge".

2) Intellectual "building pedagogy". Computer information development in entrepreneurship must have powerful intellectual tools for organizing the process of integrated education (see Bostrom \& Yudkowsky (2011); Dejoux, Léon (2018); Kornienko et al. (2015). The distinctive characteristics of such tools are the requirement of a nonlinear process of ensuring the development of business activity.

3) The applied issues of artificial intelligence in business are considered in the works (Bostrom \& Yudkowsky (2011), Weiß and Sen (1996); Kwilinski \& Kuzior (2020)). The authors highlight the problem that entrepreneurship today cannot be based on discrete data. It is necessary not only to systematize information using the latest software advances but also to provide dynamic observation in the business environment, as well as to set up an algorithm for automating decisions to reduce costs in an environment of strong competition and incomplete information.

4) In the works (Drobyazko S., et al. (2019); Drobyazko S., Barwińska-Małajowicz A., et al. (2019); Olsher (2015)) it is indicated that, unlike a fuzzy set, which expresses the inaccuracy in the assessment of a certain attribute, the measure of opportunity describes uncertainty, the incompleteness of information related to the appearance of a particular event. In fact, this is a way of quantitative description (representing the meaning) of expert judgments, which is a generalization of interval analysis and the theory of errors. Currently, the measure of opportunity and its dual measure of necessity act as the main means of modeling uncertainty in entrepreneurial activity. 
ENTREPRENEURSHIP AND SUSTAINABILITY ISSUES

ISSN 2345-0282 (online) http://jssidoi.org/jesi/

2020 Volume 8 Number 2 (December)

http://doi.org/10.9770/jesi.2020.8.2(29)

Make your research more visible, join the Twitter account of ENTREPRENEURSHIP AND SUSTAINABILITY ISSUES: @Entrepr69728810

5) In scientific works (Ceruttia et al. (2019); Mirjalili (2019)), the artificial intelligence elements design methodology based on systematic research and empirical assessment of processes in different socio-economic systems, algorithmic variations, and choice of solutions in individual activities are presented in detail.

\section{Methods}

In the current study, the methodology will be considered as a set of successive actions of practical implementation of certain research processes, their procedures and operations, which achieve the solution of the research goal. In the article, the methodology forms the structure of the study, it determines the set of relevant patterns, principles, and techniques used in the disclosure of topics and the formation of scientific novelty and conclusions. The methodological basis of the research was formed by:

1) a method of formalizing processes and logical presentation of results. In a formalized scheme, all characteristics of the complex process of functioning of the system as a whole and of its individual elements are formally determined. According to the methodology, it is necessary to formally determine the parameters of processes and states, all dependencies between the characteristics and parameters of the system as a whole and its individual elements, taking into account those factors that are taken into account during formalization. The formalized scheme contains an exact analytical formulation of the task of studying the processes of business development, the set of all initial data, known parameters of the process and initial conditions.

2) The method of variants of the structure of goals. Within the framework of this methodology, the concept of correspondence between two scales of development of complex systems - a spatial scale and a temporal one relative to entrepreneurial activity is distinguished. The principle of allocation of components at the top level of the structure of goals for solving new, unexplored problems is highlighted. The "pyramid" principle, which helps to understand the branches of the goal tree, characterizes the volume of the goal area, and experience has shown that consistent movement along the edges of the "pyramid" with a return to the highest level in the already structured branches, taking into account the new vision of the development of entrepreneurial potential helps to reveal the goal area.

3) The method of structuring goals in a fuzzy representation of business processes. For the effective organization of entrepreneurial activity, an information system is needed that allows, using computer technology and new information technologies, effectively organizing the work. In the factorial representation of the decision-making information system, these components as labor resources, material and technical support, and other objects of entrepreneurial activity are distinguished

\section{Results}

The purpose of the current study is to form organizational principles and methodological approaches to business development based on the components of artificial intelligence and fuzzy regulators in business. The purpose of the study is determined by the need to introduce new approaches to entrepreneurship, which can accelerate development and provide quality modeling of areas of activation.

The basic principle of building a fuzzy regulator in the entrepreneurship education is based on the experience formalization of the intelligent operator which manages a dynamic object by means of the linguistic rules "if ... then" (Galbraith (2014). 
Make your research more visible, join the Twitter account of ENTREPRENEURSHIP AND SUSTAINABILITY ISSUES: @Entrepr69728810

The decision-making module processes fuzzy information based on a set of linguistic rules contained in it heuristics, which are defined by the entrepreneur in the form of a language similar to the natural language of the type "If $P$, then $C^{\prime \prime}$ (González et. al. (2015). Each linguistic rule contains one or more conditions for its application and appropriate action to this condition (Fig. 1).

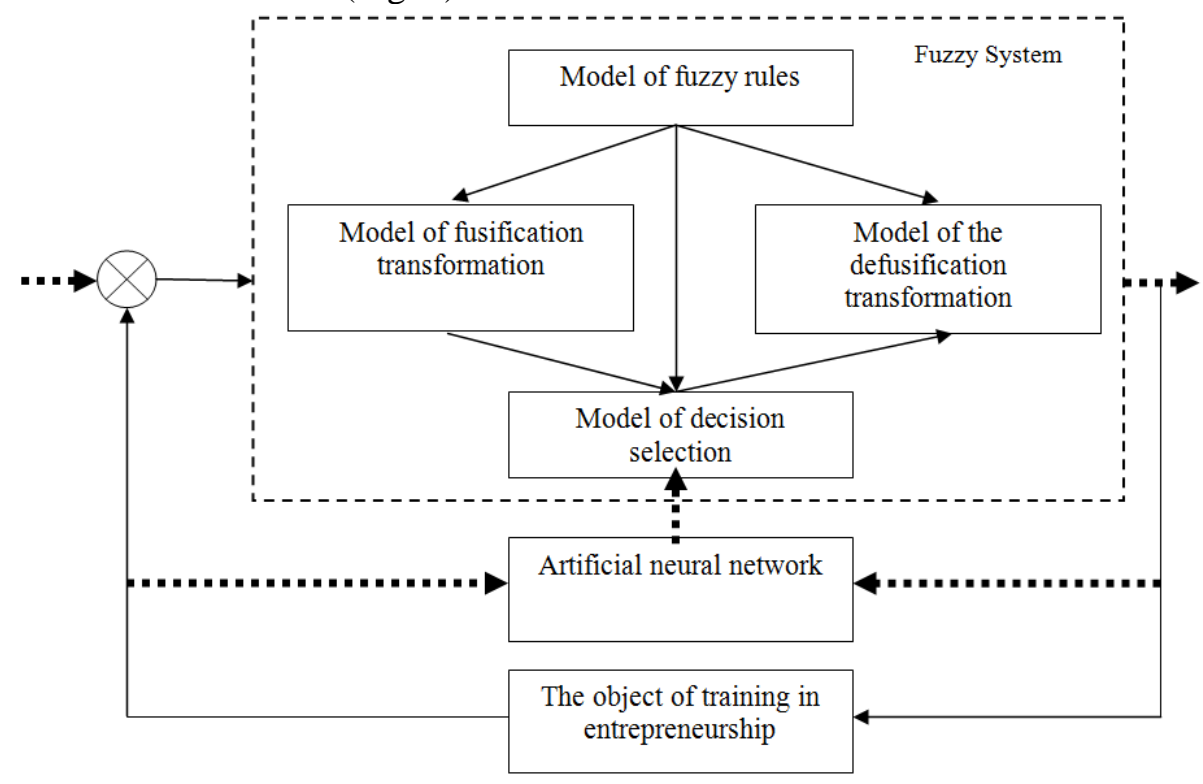

Figure 1. Architecture of fuzzy regulator in entrepreneurship development Source: the authors

Note that an additional parameter $I$ may be introduced by the expert for each fuzzy rule $W_{\mathrm{i}}$ characterizes the significance of the rule (Choe, H. \& Jordan, J.B. (1992)). Then each rule is formalized in fuzzy logic by the expert's opinion which contribution to the overall score makes a fuzzy value, and the decision selection module calculates the indicated weights (Fig. 1). Note that each rule of the system analyzes only one metric. In case when there is more than one indicator, the set of input fuzzy concepts in the rule parcel is combined by the fuzzy " $I$ " operation (Luckin (2017); Seifollahi et al. (2012):

where:

$$
\text { «if } P_{i} \text { and } P_{j} \text { and ... then } C_{t}
$$

$P$ - parameter of the fuzzy input concept;

$C$ - parameter of the fuzzy output concept;

$i$ - input number defining the index $X_{i}$ which is defined the fuzzy concepts and linguistic rule;

$j$ - number of fuzzy concept defined for input $X_{j}$.

When a logical condition consists of a set of fuzzy input parameters $P$ combined by a fuzzy conjunction operation "and". Each input fuzzy concept is implemented by a fusificator of the fuzzy controller and defined at one of the fuzzy controller inputs (the input number is identified by the label index). Generalizing the result of performing fuzzy logical transformation into a single clear value at the output of the controller is performed by the defusificator (Skute (2019). Given above about the additional parameters $W$, defusificator integrates various parameters "twos" - " $C_{i}$ and $W_{i}$. 
Make your research more visible, join the Twitter account of ENTREPRENEURSHIP AND SUSTAINABILITY ISSUES: @Entrepr69728810

Combination of the benefits of entrepreneurial development and artificial intelligence is possible through the synthesis of neuro-fuzzy systems, based on the principle of functional equivalence of architecture (Maderer (2016); Powell (1992)). The essence of the principle is interchangeable use of benefits of different classes of the architecture.

Below, we propose an algorithm for entrepreneurship development based on artificial intelligence. Activity of $F_{j}$ of each $i$-th output element of the business development system depends on the input vector $x$ as follows:

$$
F_{j}(\bar{x})=\omega_{i 0}+\sum_{i=1}^{L} v_{i j} \phi_{i}(\bar{x})
$$

where:

$\omega_{j 0}$ - threshold value of the $j$-th output;

$v_{i j}$ - weight connecting $i$-th hidden element with $j$-th output;

$\phi_{i}$ - nonlinear transformation performed by a hidden element.

The nonlinear transformation is performed by the number $L$ of the radially symmetric basis functions, precorrelating inputs with the eigenvalues of the center and deviation, i.e. $\phi_{i}(\bar{x})=\phi_{i}\left(\left\|x-c_{i}\right\| / d_{i}\right)$, where $c_{i} \in \mathfrak{R}^{n}$ is the center of the basis function $\phi_{I}$ a $d_{j}$ is deviation or scaling factor for radius $\left\|x-c_{i}\right\|$, a \|\| - usually Euclid's norm in $\mathfrak{R}^{n}$. The Gaussian form $\phi_{i}(r)=\exp \left(-r^{2} / 2\right)$ is most often used as a function $\phi$, which gives the finality of nonlinear transformation. In general, the task of development is to minimize the function of the network error $E$, which expresses the standard deviation of the network outputs from the required on a given (usually fixed) set of training pairs "input-output" during training:

$$
E=\frac{1}{2 K M} \sum_{i=1}^{K} \sum_{j=1}^{M}\left(t_{j}^{i}-o_{j}^{i}\right)
$$

where:

$K$ - number of training pairs;

$t^{i}{ }_{j}$ - the target value of the output neuron when $i$-th input image is presented to the input;

$o_{j}^{i}$ - real output of the output neuron when $i$-th input image is presented to the input; The network outputs are limited by the interval $(-1,1)$, and the target values acquire only two possible values $t_{j}^{i} \in\{-1 ; 1\}$.

As it is known, the radial elements with Gaussians have one very important property - action locality - the function influence can be neglected $\phi_{i}$ at a distance of more than $2 d_{i}$ from the center $c_{i}$. This property makes it possible to evaluate the efficiency of each element independently of the others, thus to independently select the elements in the next generation. It significantly accelerates convergence of the algorithm. The following function is used to evaluate efficiency of the individual element $\phi_{j}$, which coincides with the defusification function by virtue of the principle of functional equivalence: 
Make your research more visible, join the Twitter account of ENTREPRENEURSHIP AND SUSTAINABILITY ISSUES: @Entrepr69728810

$$
e_{j}=\frac{\sum_{x_{k} \in r} \phi_{j}\left(\overline{x_{k}}\right)}{\sum_{k=1}^{L} \phi_{j}\left(\overline{x_{j}}\right)}
$$

where:

$e_{j}$ - efficiency value of $j$-th element;

$\phi_{j}\left(\overline{x_{j}}\right)$ - output value of $j$-th element when the image is submitted to the input;

$x_{k}$ - images of the instructive class sample $r$, the sum of the outputs is maximum for them.

This function determines how much this element $\phi_{j}$ distinguishes the class $r$ from the training images of all other classes. The initial rule strategy is to maximize the values $e_{j}$ for all hidden network elements. The first stage of the calculating efficiency provides finding of the values which this neuron picks up in each class. Then the maximum value is selected among these quantities and correlated with the total activity of the radial element. The great advantage of this function is the following - it does not require knowledge of the output weights (Kathirvel et. al., 2019). Thus, it is possible to improve the centers and deflections of the elements without developing the input parameters in the enterprise, which greatly reduces the average time of one iteration.

The above function (4), unfortunately, does not meet these requirements. Its use in the input space implies minimums which the element seeks to occupy. As much as possible, the duplication degree of two radial elements $\phi_{i}$ and $\phi_{j}$ is expressed as the orthogonality of the vectors of the normalized activities of these elements on the initial sample images:

$$
R_{i j}=\frac{\sum_{k=1}^{K} \phi_{i}\left(\overline{x_{k}}\right) \phi_{j}\left(\overline{x_{k}}\right)}{\sqrt{\sum_{k=1}^{K} \phi_{i}^{2}\left(\overline{x_{k}}\right) \phi_{j}^{2}\left(\overline{x_{k}}\right)}}
$$

Note that if the radial elements aren't intersected, then $R_{i j}$ equals to zero (i equals to one if work of neurons is completely identical). Accurately calculation of the orthogonality activities for all pairs of elements is quite a time-consuming procedure. Therefore, it's needed a compromise solution requiring much smaller calculations: we will only use the maximum activity condition for each of the radial elements $(p<<K)$ to determine excessively competing elements; $p$ often equals to 1 or 2 , and others are equal to zero. If the result is not zero, then elements $\phi_{i}$ and $\phi_{j}$ are considered as duplicates.

The given block of formulas defines a methodical approach concerning introduction of a neuro-fuzzy regulator in business activity. At the same time, there is a need to determine the basic set of risks and threats to the development of business stabilization of a particular business entity in order to select a clear neural regulator or their composition for further use and business effects.

The main distinguishing features of an adaptive entrepreneurial development model are the presence of subjective expert's knowledge (represented by a set of linguistic rules) and development procedures based on objective data from the subject area (see Weiß and Sen, 1996). Note that the development procedure for the model of adaptive 
ENTREPRENEURSHIP AND SUSTAINABILITY ISSUES

ISSN 2345-0282 (online) http://jssidoi.org/jesi/

2020 Volume 8 Number 2 (December)

http://doi.org/10.9770/jesi.2020.8.2(29)

Make your research more visible, join the Twitter account of ENTREPRENEURSHIP AND SUSTAINABILITY ISSUES: @Entrepr69728810

neuro-fuzzy controller allows to automate the selection process of internal parameters of the controller, depending on the "quality" of external parameters (Fig. 2).

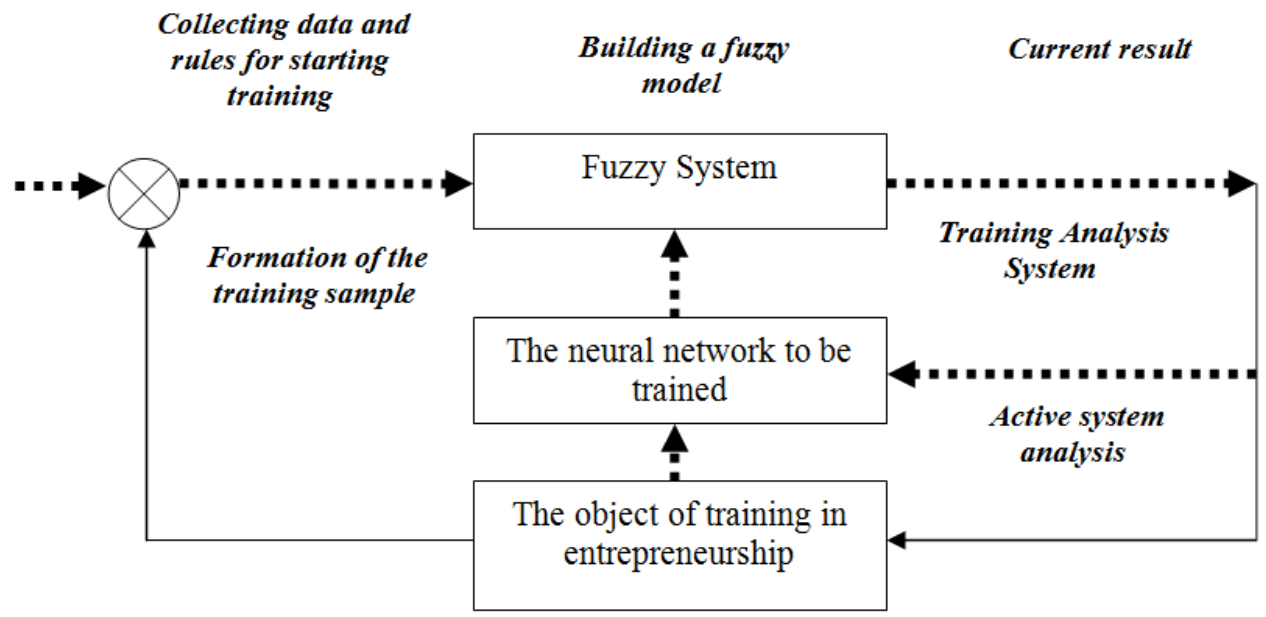

Figure 2. Architecture of the adaptive neuro-fuzzy regulator development in entrepreneurship

Source: the authors

A logical structure of entrepreneurial development is formed at the first stage, which establishes a set of linguistic rules by an expert. Describing a specific set of rules, the expert thereby sets out a strategy to achieve the goal of the system (for example, for a management task, the goal may be successful management of entrepreneurial development) (Metelenko et. al., 2019).

At the second stage the designed system of adaptive development is considered as an adaptive network with a fixed structure and corresponding set of changing parameters, its values can be changed by the genetic algorithm of parametric development of neural networks based on the used real assessments of the work quality by the algorithm.

From a functional point of view, the genetic algorithm (GA) is an active "black box". GA uses an analogue of a biological individual and its natural genotype for implementing a genetic mechanism of the useful information accumulation and search. If a priori data from the external environment are absent, GA searches for the highest evaluated solutions, based only on the estimates of the solutions previously offered by them (Olsher, 2015).

Distinctive properties of the solution (individuals) are stored in a special data set - the artificial chromosome which creates the genotype of the individual. In this model, which optimizes the process of management, the quality criterion $-\mathrm{K}$ is used as the criterion for solving the optimization problem, the set of $\mathrm{Pj}$ values, ie the tuning parameters is used as an artificial intelligence individual. The values of $\mathrm{Pj}$ are encoded in the chromosome by the distinguishing properties of the solution of the problem and they are proposed to be considered as a set, which we denote as P. Artificial intelligence initialized by a specific set of tunable parameters values $P_{j}$, set of $P_{j}$, parameter values $P$ is the coded in chromosome distinctive properties of the solution

For the case of a fuzzy controller, the genetic algorithm can be used to calculate the values of $W_{i}$ of linguistic rules based on statistics about results of the common activity of the fuzzy controller and the object of the entrepreneurial development. Obviously, the optimal values of the weights $W_{i}$ will be the values which characterize the minimal difference between the estimates of the artificial intelligence work and the real estimates. 
ENTREPRENEURSHIP AND SUSTAINABILITY ISSUES

ISSN 2345-0282 (online) http://jssidoi.org/jesi/

2020 Volume 8 Number 2 (December)

http://doi.org/10.9770/jesi.2020.8.2(29)

Make your research more visible, join the Twitter account of ENTREPRENEURSHIP AND SUSTAINABILITY ISSUES: @Entrepr69728810

Then the objective function is calculated based on the Euclid distance between the vector formed by the set of estimates provided by the development system and the vector consisting of real estimates by the following formula:

$$
\bar{Y}=\frac{1}{D} \sqrt{\sum_{i=1}^{D}\left(Y^{d}-R^{d}\right)}
$$

$\bar{Y}$ - target function;

$Y^{d}$ - estimate predicted by the development system for the solution $d$;

$R^{d}$ - real estimate for the solution $d$;

$d$ - decision number;

$D$ - number determining the number of solutions (number of GA attempts to find the optimal solution).

Thus, the vector of weights significance $W_{i}$ serves as the set of optimizable parameters. The specific set of values $W_{i}$ determines some solution of the optimization problem (individual) stored in the GA chromosome. The automatic management system is formed from the object of development (OS) and the adaptive neuro-fuzzy network. The current status of the OS $S_{i}$ enters the input at each moment of time $t_{i}$. Based on it the artificial intelligence forms the action $F_{i}$, which enters the OS and thereby close the feedback. The goal of the neuro-fuzzy process is to bring the OS from its current status $S_{i}$ to the target state $S_{\text {tar }}$ through the management action $F_{i}$. The management carried out by a neuro-fuzzy network depends on its logical structure, as well as the values taken by the many customizable parameters presented in it. If the logical structure of the neuro-fuzzy network can be completely determined based on the entrepreneur's knowledge of the OS management, then the values of the tunable parameters are only identified approximately (Talatahari et. al., 2012).

As a result, opportunity of improvement the work of the artificial intelligence model is arisen by finding a set of parameters values of the neuro-fuzzy network, quality optimizing some criterion $-K$ management of OS.

Calculation of the quality assessment of the neuro-fuzzy network is realized by the block calculator of the development criterion. This calculator has ability to initiate a sequence from $N$ tests of the work of the neurofuzzy network. At the beginning of each test, an OS is initialized by some initial status $S_{k}{ }_{k}$, after the functioning of an OS is simulated under artificial intelligence, during this process it tries to bring the system from its initial status $S^{0}{ }_{k}$ to the target $S_{\text {tar }}$. The development system monitors the status of OS $S_{k}^{i}$ at each moment of discrete time $t_{i}$. Based on these observations, the development system calculates the assessment of the work quality of the neuro-fuzzy network in the test (taking into account success, speed and accuracy of aspirations $S_{k}^{i}$ to $S_{\text {tar }}$ ). The criterion value $K_{j}$, corresponded to the tested parameter set $P_{j}$ in the neuro-fuzzy network, is calculated as an integral estimate with relatively to the estimates calculated in the individual tests.

The process of optimization of the adaptive neuro-fuzzy network is divided into cycles, each of them evaluates one variant of the optimization problem solution defined by some set of parameter values $P_{j}$. The following actions are performed in each cycle: GA issues another estimated set of parameters values $P_{j}$ which initiated the artificial intelligence block.

The search process implemented by GA tends to find and make better solutions in optimization cycles. Thus, after a certain number of optimization cycles, an optimal set of values $P_{\text {opt }}$ having maximized $K$ can be obtained. In this case, management carried out by a set of values $P_{\text {opt }}$ initialized, will be optimal in the sense of the entered criterion of quality management $K$. 


\section{ENTREPRENEURSHIP AND SUSTAINABILITY ISSUES}

ISSN 2345-0282 (online) http://jssidoi.org/jesi/ 2020 Volume 8 Number 2 (December)

http://doi.org/10.9770/jesi.2020.8.2(29)

Make your research more visible, join the Twitter account of ENTREPRENEURSHIP AND SUSTAINABILITY ISSUES: @Entrepr69728810

Studies in the development of real models have shown that the second (stochastic) method is more acceptable for real objects. The formulas for calculating the criterion $K$ can be determined in the case of an arbitrary OS. It is necessary: to highlight a subset of the initial status variables in a set of OS status variables; to attribute weights of relative importance to them; to express the goal of management over the value of OS status variables and to introduce an algorithm for setting initial OS statuses in tests by any of the above methods (March, 1991).

The chromosome is a bit-bit grid broken down into sections. Each section has a certain parameter, such as the weight of the linguistic rule $W_{i}$. In general, the chromosome encodes the initial set of weights, i.e. parameters of the tunable neuro-fuzzy system. It is obviously that each parameter $W_{i}$ corresponds to several bits of the chromosome for the numerical representation of this parameter and, thus, the search range for the parameter representation. Different combinations of the parameter values cannot exceed the range. In the general case, the order of the presented parameters, their number and the bit of each parameter may vary at the initial chromosome task, but in the future, the accepted representation of the encoding information in the form of a chromosome remains unchanged (De Lange, 2015). Considering the accepted method of encoding individual parameters, the complete chromosomal set is a sequence obtained by combination of bit representations of some number $n$ of the tunable parameters, as shown in Fig. 3.

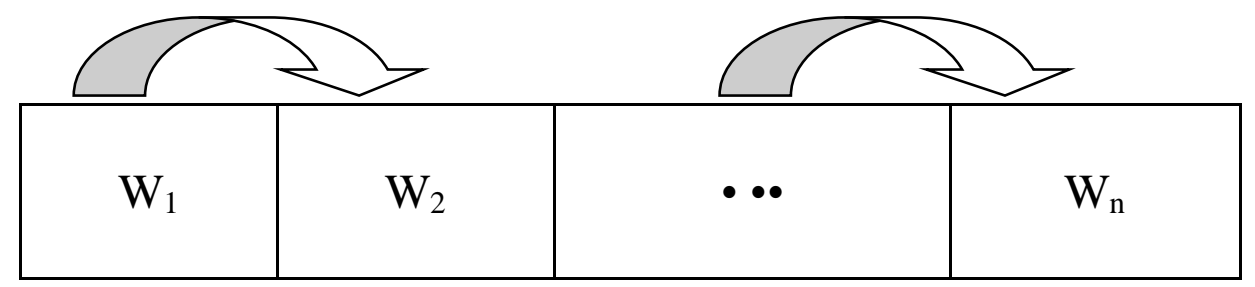

Figure 3. Bit sequence of encoding by the chromosome parameters of the neuro-fuzzy entrepreneurial development (Mallonas, 1994)

The GA procedure operates with multiple chromosomes (population of individuals), modeling the "natural tools" of evolution: competition of individuals, reproduction of individuals with the inheritance of the genes of the parents in the descendants, gene mutation.

The essence of the genetic search procedure for the adaptive neuro-fuzzy regulator in business education proposed in the paper is as follows.

$1^{\circ}$ To generate randomly the initial plural population of $n$ chromosomes.

$2^{\circ}$ To evaluate each chromosome of the population using a target function (optimization criterion). The evaluation of each chromosome is done by decoding the neuro-fuzzy controller into a set of parameters values, initialization of the neuro-fuzzy controller by the obtained set of parameters, conducting tests according to the algorithm of entrepreneurial development and calculating the value of the criterion $K_{j}$ which is estimation of the chromosome.

$3^{\circ}$ To break the population of individuals into random pairs and to generate two descendants from each pair by the use of crossover operators with probability $p_{c}$ and mutations with probability $p_{m}$. Dividing population into random pairs is implemented by performing $n$ random paired permutations in the list of population's individuals and further merging into pairs of neighbors on the list, for example $(1-2,3-4, \ldots, n-l-m)$. Generation of the descendants' pair is carried out in two stages. The first stage determines the occurrence of a random event relative to the crossover, based on the probability $p_{c}$. 
ENTREPRENEURSHIP AND SUSTAINABILITY ISSUES

ISSN 2345-0282 (online) http://jssidoi.org/jesi/

2020 Volume 8 Number 2 (December)

http://doi.org/10.9770/jesi.2020.8.2(29)

Make your research more visible, join the Twitter account of ENTREPRENEURSHIP AND SUSTAINABILITY ISSUES: @Entrepr69728810

The crossover and mutation operators work with the chromosomes as a homogeneous bit sequence, without isolating fragments representing individual parameters of the neuro-fuzzy system. The crossover operator has two parental chromosomes at the input and generates two descendants' chromosomes constructed from the genes (bits) of the parental chromosomes. Figure 4 explains the content of a "simple one-point crossover".

$4^{\circ}$ To evaluate received $n$ descendants using the target function. The assessment is made in a similar manner to the method described in item 2.

$5^{\circ}$ To choose $n$ the best individuals for the next generation from joint variety of the sizes $2 n$ of parents and descendants.

"Parents":

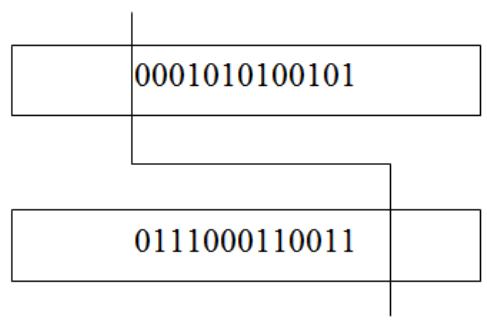

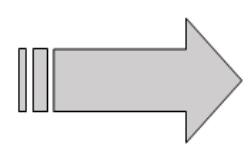

"Descendants":

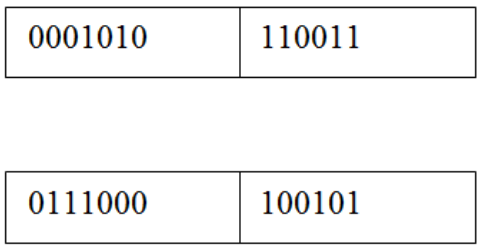

Figure 4. Model of a one-point crossover in the artificial intelligence system

The "softness" of selection is needed to prevent premature convergence of the algorithm to a solution in which the global optimum can be missed due to the small number of GA iterations. The 'roulette' mechanism does not guarantee that the best decision in the population will be preserved in the next generation (Schuhmacher \& Kuester, 2012).

$6^{\circ}$ The end of the procedure in case of its completion, otherwise transition to item 3 . The fact of the achieving an estimate of the best chromosome in the current population is considered as the main condition of completion, as well as the condition of stopping the algorithm for exceeding the specified number of iterations $N_{\max }$ of the genetic algorithm is taking into account.

As a result, the novelty of the study is the neural network model in entrepreneurial development through which the business entity can model variations in the development of entrepreneurial initiatives, identify strengths and weaknesses of new projects, and compare alternative business options in terms of profitability and costs.

\section{Discussion}

Prospective recommendations in the field of entrepreneurship and artificial intelligence can be formed in the context of the model synthesis of the neuro-fuzzy execution of the functional equivalence procedure of the basic elements of fuzzy networks and artificial neural networks. This approach will help to formulate the task of the model synthesis of the adaptive neuro-fuzzy regulator. Such model will allow to transform the neural network development algorithm into a fuzzy system in the future and, thus, to use neural network optimization algorithms for fuzzy systems in business education. The main distinguishing features of the adaptive model are the presence of subjective expert's knowledge and development procedures based on objective data from the subject area. 


\section{ENTREPRENEURSHIP AND SUSTAINABILITY ISSUES}

ISSN 2345-0282 (online) http://jssidoi.org/jesi/

2020 Volume 8 Number 2 (December)

http://doi.org/10.9770/jesi.2020.8.2(29)

Make your research more visible, join the Twitter account of ENTREPRENEURSHIP AND SUSTAINABILITY ISSUES: @Entrepr69728810

\section{Conclusions}

It is determined that the fuzzy model of the regulator integrates the capabilities of the fuzzy system to incorporate knowledge in the form of linguistic rules set by the entrepreneur in the process of beginning development. The optimization process leads to the need to take into account the interplay of not only linguistic rules on the efficiency of the fuzzy controller, but also the interplay of fuzzy parameters within one rule. The variant model of the neuro-fuzzy controller proposed in the paper allows integration of the fuzzy system capability to incorporate entrepreneur knowledge in the form of linguistic rules, as well as possibility of neural networks to develop.

A set of rules for the use of the fuzzy choice was formed, which will allow considering the result of the fuzzy choice as an investment of the fuzzy factor in the criterion space as a set of fuzzy one-dimensional criteria that characterize the state of the entrepreneurial system at certain intervals. A methodological approach to fuzzy choice has been developed, in which the choice function is formed from the choice functions for individual fuzzy relations, and the choice can occur in several stages. The mechanism of sequential fuzzy choice and the mechanism of parallel fuzzy choice are formally defined.

\section{References}

Axelrod, R. (1997). The complexity of cooperation: Agent-based models of competition and collaboration. Princeton, NJ: Princeton University Press.

Bostrom, N., \& Yudkowsky, E. (2011). The ethics of artificial intelligence. In K Frankish, WM Ransey (Eds.), Cambridge handbook of artificial intelligence, (pp. 316-334). Cambridge, UK: Cambridge University Press.

Dejoux C. Léon E. (2018). Métamorphose des managers. 1st edition. France: Pearson.

Cerutti, F., Giacomin M., Vallati M. (2019). How we designed winning algorithms for abstract argumentation and which insight we attained. Artificial Intelligence, 276, 1-40

Choe, H. \& Jordan, J.B. (1992). On the Optimal Choice of Parameters in a Fuzzy C-means Algorithm, Proc. IEEE International Conference on Fuzzy Systems, San Diego, 349-354.

De Lange, C. (2015). Welcome to the bionic dawn. New Scientist, 227(3032), 24-25.

Galbraith, J. (2014). Organization design challenges resulting from Big Data. Journal of Organization Design, 3(1), 2-13.

González, V.M., Robbes, R., Góngora, G., Medina, S. (2015). Measuring concentration while programming with low-cost BCI devices: differences between debugging and creativity tasks. In Foundations of augmented cognition, (pp. 605-615). Los Angeles, CA, Springer International Publishing.

Drobyazko S., Barwińska-Małajowicz A., Ślusarczyk B., Zavidna L., Danylovych-Kropyvnytska M. (2019). Innovative Entrepreneurship Models in the Management System of Enterprise Competitiveness. Journal of Entrepreneurship Education, 22(4), https://www.abacademies.org/articles/Innovative-entrepreneurship-models-in-the-management-system-1528-2651-22-4-408.pdf

Drobyazko S., Okulich-Kazarin V., Rogovyi A., Goltvenko O., Marova S. (2019). Factors of Influence on the Sustainable Development in the Strategy Management of Corporations. Academy of Strategic Management Journal. 18(Special Issue; Title: Strategic Research Directions) URL: https://www.abacademies.org/articles/Factors-of-influence-on-the-sustainable-development-in-the-strategy-managementof-corporations-1939-6104-18-SI-1-439.pdf

Kathirvel, V., Asyraf Mansor, M., Shareduwan, M., Kasihmuddin, M., Sathasivam, S. (2019). Hybrid imperialistic competitive algorithm incorporated with hopfield neural network for robust 3 satisfiability logic programming. IAES International Journal of Artificial Intelligence (IJ-AI), 8(2), 144-155 
ENTREPRENEURSHIP AND SUSTAINABILITY ISSUES

ISSN 2345-0282 (online) http://jssidoi.org/jesi/

2020 Volume 8 Number 2 (December)

http://doi.org/10.9770/jesi.2020.8.2(29)

Make your research more visible, join the Twitter account of ENTREPRENEURSHIP AND SUSTAINABILITY ISSUES: @Entrepr69728810

Kornienko, A.A. Kornienko, A.V. Fofanov, O. Chubik, M. (2015). Knowledge in artificial intelligence systems: searching the strategies for application. Procedia - Social and Behavioral Sciences, 166, 589-594.

Kwilinski, A., \& Kuzior, A. (2020). Cognitive Technologies in the Management and Formation of Directions of the Priority Development of Industrial Enterprises. Management Systems in Production Engineering, 28(2), 133-138. https://doi.org/10.2478/mspe-2020-0020

Luckin, R. (2017). Towards artificial intelligence-based assessment systems. Nature Human Behaviour, 1(0028). http://doi.org/10.1038/s41562-016-0028

Maderer, J. (2016). Artificial intelligence course creates AI teaching assistant. Georgia Tech News Center, 9 May 2016. http://www.news.gatech.edu/2016/05/09/artificial-intelligence-course-creates-ai-teaching-assistant

Makedon, V., Kostyshyna, T., Tuzhylkina, O., Stepanova, L., Filippov, V. (2019). Ensuring the efficiency of integration processes in the international corporate sector on the basis of strategic management. Academy of Strategic Management Journal, Volume 18, Special Issue 1, 2019: URL: https://www.abacademies.org/articles/Ensuring-the-efficiency-of-integration-processes-in-the-international-corporatesector-on-the-basis-of-strategic-management-1939-6104-18-SI-1-452.pdf

March, J. G. (1991). Exploration and exploitation in organizational learning. Organization Science, 2, 71-87.

Metelenko, N.G., Kovalenko, O.V., Makedon, V., Merzhynskyi, Y.K., Rudych, A.I. (2019). Infrastructure security of formation and development of sectoral corporate clusters. Journal of Security and Sustainability Issues 9(1), 77-89. http://doi.org/10.9770/jssi.2019.9.1(7)

Mirjalili, S. (2019). Evolutionary Radial Basis Function Networks. in Studies in Computational Intelligence, $105-139$. https://doi.org/10.1007/978-3-319-93025-1_8

Olsher, D.J. (2015). New Artificial Intelligence Tools for Deep Conflict Resolution and Humanitarian Response. Procedia Engineering, $107,282-292$.

Petruzzi, N.C., Dada, M., (2002). Dynamic pricing and inventory control with learning. Naval Research Logistics 49, $304-325$.

Powell, M. J. D. (1992). The theory of radial basis functions approximation, in Advances of Numerical Analysis Oxford: Clarendon Press

Ratten, V.; Ferreira, J.J. (2016). Sport Entrepreneurship and Innovation, 1st ed.; Taylor \& Francis: New York, NY, USA.

Russell, S.J., \& Norvig, P. (2010). Artificial intelligence: a modern approach, (3rd ed.). Upper Saddle River: Prentice-Hall.

Schuhmacher, M.C., Kuester, S. (2012). Identification of lead user characteristics driving the quality of service innovation ideas. Create Innovation Management, 21, 427-442.

Seifollahi, S., Yearwood, J. and Ofoghi, B. (2012). Novel weighting in single hidden layer feedforward neural networks for data classification. Computers \& Mathematics with Applications, 64(2), 128-136.

Skute, I. (2019). Opening the black box of academic entrepreneurship: A bibliometric analysis. Scientometrics, 24 , 1-29.

Snow, C.C., Fjeldstad, Ø.D., Langer, A.M. (2017). Designing the digital organization. Journal of Organization Design, 6(7), 1-13

Talatahari, S., Azar, B.F., Sheikholeslami, R. and Gandomi, A.H. (2012). Genetic algorithm combined with chaos for global optimization. Communications. Nonlinear Science and Numerical Simulation, 17(3), 1312-1319.

Walker, I. (2010). Research Methods and Statistics: Palgrave Insights in Psychology Series, 1st ed. New York: Palgrave Macmillan.

Weiß, G. and Sen, S. (eds.) (1996). Adaptation and Learning in Multiagent Systems, Springer Verlag, Berlin.

Whitehead, B.A. and Choate, T. D. (1994). Evolving space-filling curves to distribute radial basis functions over an input space. IEEE Transactions on Neural Networks, 5(1), 15-23 


\section{ENTREPRENEURSHIP AND SUSTAINABILITY ISSUES}

ISSN 2345-0282 (online) http://jssidoi.org/jesi/

2020 Volume 8 Number 2 (December)

http://doi.org/10.9770/jesi.2020.8.2(29)

Make your research more visible, join the Twitter account of ENTREPRENEURSHIP AND SUSTAINABILITY ISSUES: @Entrepr69728810

\section{Aknowledgements}

This research was supported by the project, which has received funding from the Grant No. 1/0544/19 Formation of the methodological platform to measure and assess the effectiveness and financial status of non-profit organizations in the Slovak Republic

Sergii BOGACHOV, Doctor of Economic Science, Professor, PO "Institute for Local and Regional Development

ORCID ID: orcid.org/0000-0002-8938-0315

Aleksy KWILINSKI, Ph.D., Habilitated Doctor in Economics, The London Academy of Science and Business, London, England ORCID ID: orcid.org/0000-0001-6318-4001

Boris MIETHLICH, PhD, Faculty of Management, Comenius University in Bratislava, Slovak Republic ORCID ID: orcid.org/0000-0003-4064-6722

Viera BARTOSOVA, Ph.D in Economics, Associate Professor, University of Zilina, Slovak Republic ORCID ID: orcid.org/0000-0001-7960-4429

Aleksandr GURNAK, PhD, Associate Professor, Financial University under the Government of the Russian Federation ORCID ID: orcid.org/0000-0002-4514-6885

Copyright (C) 2020 by author(s) and VsI Entrepreneurship and Sustainability Center

This work is licensed under the Creative Commons Attribution International License (CC BY).

http://creativecommons.org/licenses/by/4.0/

(C) (i) Open Access 